\title{
Structure and dynamics of a high-latitude scleractinian coral community in Amakusa, southwestern Japan
}

\author{
Yoko Nozawa ${ }^{1, *}$, Mutsunori Tokeshi ${ }^{2}$, Satoshi Nojima ${ }^{2}$ \\ ${ }^{1}$ Biological Institute on Kuroshio, 560 Nishidomari, Otsuki-Hata, Kochi 788-0333, Japan \\ ${ }^{2}$ Amakusa Marine Biological Laboratory, Kyushu University, Tomioka 2231, Reihoku-Amakusa, Kumamoto 863-2507, Japan
}

\begin{abstract}
This study examined structure and dynamics of a high-latitude scleractinian coral community in Amakusa, southwestern Japan $\left(32^{\circ} \mathrm{N}\right)$. All visible colonies ( $>5 \mathrm{~mm}$ in diameter) in an area of $100 \mathrm{~m}^{2}$ were monitored for $2 \mathrm{yr}$ (2001 to 2003). A total of 54 species belonging to 30 genera in 13 families were identified from 2471 colonies that covered $28.3 \%$ of the area in 2001 . The majority of these were spawners with only 4 brooding species being identified or inferred. Faviidae was the most specious family (21 spp.), being dominant in terms of both colony number $(49.8 \%)$ and cover $(55.4 \%)$. In spawning genera, frequency distributions of colony sizes were characterized by a larger median size, wide size range and a tendency toward negative skewness, whereas in brooding genera, highest frequencies were in small size classes with a tendency toward positive skewness. Annual recruitment, dominated by Acropora and 3 brooding genera, was relatively constant (122 to 132 recruits) but always lower than annual mortality (death/dislodgement, 187 to 288 colonies), resulting in a rapid reduction in colony number $(9 \%)$ in the 2 yr study period. Acropora and brooding genera accounted for $79 \%$ of the community turnover (mortality and recruitment) while many genera showed little or no change. Pocillopora showed the largest increase (+36 colonies) and Acropora the largest decrease $(-127$ colonies). During the study period, 57 colonies of middle to large size were lost (i.e. no skeleton remained) due to severe wave action caused by rough weather or typhoons, while colonies that died from other causes (418 colonies) were mostly of small sizes. Consequently, though deaths accounted for $88 \%$ of colony losses, lost colonies (i.e. those not counted as 'dead') accounted for $75 \%$ of coral cover reduction. This occasional loss of large colonies by severe wave action is likely to be a significant factor inhibiting the development of scleractinian communities and reef accretion, especially at high latitudes where these processes are considered to be slow.
\end{abstract}

KEY WORDS: Scleractinian corals · High latitudes · Community structure · Community dynamics · Spawning species $\cdot$ Brooding species $\cdot$ Severe wave action Resale or republication not permitted without written consent of the publisher

\section{INTRODUCTION}

Despite the occurrence of many scleractinian coral species with extensive cover at high latitudes, there has been only a limited number of detailed ecological studies of these communities. Studies of the dynamics of high-latitude coral communities provide essential information for conservation and management strategies, which need to take into account various factors that are important in high-latitude systems (Harriott \&
Banks 2002). These dynamics studies also look into processes underlying the distributional limits of coral species and coral reefs (Harriott \& Banks 2002).

Demographic approaches that can detect changes in cohort structure are more useful than monitoring surveys that merely document changes in coral cover, as the former is more amenable to analysing and hypothesising about mechanisms underlying community dynamics and species coexistence (Tokeshi 1999). Demographic approaches should encompass both 
long-term monitoring and detailed short-term studies that complement each other to provide information on vital population processes such as birth, death, immigration and emigration.

Colony-size frequency distribution is a useful analytic tool that can reveal demographic structures of community members at various taxonomic levels. Recent developments in underwater survey methods have enabled the use of colony surface area in analyses of sizefrequency distributions; this is a more accurate and representative measure of colony size than colony length (i.e. diameter) (Bak \& Meesters 1998, Meesters et al. 2001, Vermeij \& Bak 2002). This is important because reproductive capability and mortality of scleractinian coral species depend on colony area (Babcock 1991, Hall \& Hughes 1996). The use of colony area also increases resolution in demographic analyses, especially with smaller size classes, which constitute the majority of coral populations (Babcock 1991, Bak \& Meesters 1998, Meesters et al. 2001).

In this study, a detailed annual survey was conducted to monitor all visible colonies (> 5 $\mathrm{mm}$ in diameter) within a total area of $100 \mathrm{~m}^{2}$ at a high-latitude site $\left(32^{\circ} \mathrm{N}\right)$ in Amakusa, southwestern Japan. The results of this study provide, for the first time, detailed demographic information on the community structure and 2 yr dynamics of a high-latitude scleractinian coral assemblage in Japan.



Fig. 1. Study site (㐫) at Satsukigaura, Amakusa, southwestern Japan

\section{MATERIALS AND METHODS}

The study site was located on the eastern side of a small bay (Satsukigaura) $\left(32^{\circ} 10^{\prime} \mathrm{N}, 130^{\circ} 02^{\prime} \mathrm{E}\right)$ in Amakusa, southwestern Japan (Fig. 1). In the study site the substrate consisted of rocky outcrops with a mixture of sand, pebbles and boulders, and scleractinian corals formed patchy assemblages on the upper surfaces of rocky substrata. A total of 98 scleractinian coral species have been recorded from this and surrounding sites in the islands of the Amakusa archipelago (Veron 1992, Nishihira \& Veron 1995), of which approximately half are known to develop mature gonads (45 spp.) and/or release gametes (24 spp.), or release planular larvae (2 spp.) between July and September (Yeemin 1991, Thamrin et al. 2001, Tioho et al. 2001, Nozawa et al. 2006). Seawater temperature at the study site was monitored at $2 \mathrm{hr}$ intervals: weekly average values ranged from $\sim 15^{\circ} \mathrm{C}$ (in February to March) to $\sim 27^{\circ} \mathrm{C}$ (in August to September) (see Nozawa et al. 2006 for details).

Preliminary snorkel and SCUBA surveys were used to establish monitoring plots that were relatively flat with a well-developed coral assemblage at the study site. Five $20 \mathrm{~m}^{2}$ plots, separated at a distance of 0 to $6 \mathrm{~m}$, were established at $\sim 5 \mathrm{~m}$ in depth (four $4 \times 5 \mathrm{~m}$ rectangular plots and one $4 \times 4 \mathrm{~m}$ square plot plus 4 continuous $1 \times 1 \mathrm{~m}$ square areas). The plots were divided into $1 \times 1 \mathrm{~m}$ square areas and yellow plastic disks ( $5 \mathrm{~cm}$ in diameter) were attached to each corner using underwater glue.

Monitoring was conducted annually in October and November in 2001, 2002 and 2003. In 2001, each $1 \times$ $1 \mathrm{~m}$ square area in the plots was temporarily subdivided into 16 square areas of $25 \times 25 \mathrm{~cm}$, using firstly $50 \times 50 \mathrm{~cm}$ and then $25 \times 25 \mathrm{~cm}$ square quadrats. Each $25 \times 25 \mathrm{~cm}$ square area was photographed with a scale from above, and all visible-sized colonies ( $>\sim 5$ $\mathrm{mm}$ in diameter) in the area were mapped using underwater paper and pencil. Colonies larger than 25 $\times 25 \mathrm{~cm}$ and small colonies $(<\sim 5 \mathrm{~cm}$ diameter) were also photographed individually with a scale from above. In this study, a colony was defined as a structural unit; a group of fragmented tissues due to death of intervening parts on a single skeleton was treated as a single colony. In subsequent years (2002 and 2003), survival of each colony recorded in 2001 was tracked on distribution maps by subdividing each $1 \times$ $1 \mathrm{~m}$ square area into $25 \times 25 \mathrm{~cm}$ square areas. Besides dead colonies (skeleton remaining), colonies that were separated from substrata and completely lost (i.e. no skeleton remaining) from the plots due to severe wave action were also recorded. For single colonies consisting of a group of fragmented colonies, dead or lost colonies were only counted as such when 
the last colony in the group was dead or lost. Any recruit, defined as a newly appeared recruit-sized colony ( $<2 \mathrm{~cm}$ in diameter), was photographed with a scale from above and added to the maps each year. Although several colonies larger than this size were found every year, these were considered as colonies missed in previous year(s) and were excluded from analyses.

Species were identified according to Veron (2000), using (1) close-up photographs of whole colonies and polyps and (2) section samples of conspecific colonies collected with a hammer and a chisel in areas outside the plots. The samples were bleached in a chlorine solution and then submitted to taxonomic assessment. All colonies that had $>50 \%$ of area falling within the plots were included in the analyses. Relative surface area (i.e. projected area) of living tissue(s) of each colony was determined from photographs taken in 2001 using Scion Image software (Scion Corp.), and was used as 'colony size.'

Colony size data in 2001 were logarithmically transformed and used for the analyses of size-frequency distribution, as log-transformed (normalized) data are thought to reflect age distribution more closely than non-transformed ones (Bak \& Meesters 1998, Vermeij $\&$ Bak 2002). For the most frequent 15 genera (in colony number) some descriptive statistics including median, range, kurtosis and skewness, were calculated and compared between spawning and brooding genera. Normality of the distribution was tested using a D'Agostino-Pearson test with Bonferroni correction (Zar 1999). Where the p value was $<0.05$, departure of kurtosis and skewness from normality was further tested using an Anscombe-Glynn test of kurtosis and a D'Agostino test of skewness, both with Bonferroni correction (Zar 1999).

The effect of colony size on colony fate at the end of the 2 yr study period (i.e. live, dead or lost) was analysed at community and genus levels. For community level analysis the difference in colony-size frequency distributions between live, dead and lost colonies was tested using a Kruskal-Wallis test with a Dunn's multiple comparison test (Zar 1999). For genuslevel analyses, genera that had $>5$ colonies each in the dead and/or lost colony categories were used. For 9 genera that had $>5$ dead or lost colonies, differences in size distribution between live and dead or lost colonies were tested using a Kolmogorov-Smirnov 2-sample test with Bonferroni correction. For 3 genera that had $>5$ dead colonies and >5 lost colonies, differences in size distribution between live, dead and lost colonies were tested using a Dunn's multiple comparison test (Zar 1999) with Bonferroni correction. All statistical analyses were executed with $\mathrm{R}$ software ( $\mathrm{R}$ Development Core Team 2005).

\section{RESULTS}

\section{Community structure}

A total of 2471 colonies, covering $28.3 \%$ of the $100 \mathrm{~m}^{2}$ monitoring area, were recorded in 2001. Most colonies occurred on rocky substrata while some colonies were found on dead coral skeletons. Altogether, 54 species of scleractinian coral belonging to 30 genera and 13 families were identified (Table 1), of which 6 species were newly recorded in this region (i.e. Alveopora sp., Coscinaraea crassa, Favia maxima, Goniastrea pectinata, Lithophyllon lobata, Pavona varians) (cf. Veron 1992, Nishihira \& Veron 1995). While the majority of the 54 species were spawners, 3 brooding species (i.e. A. cf. japonica, Thamrin et al. 2001; Alveopora sp., Y. Nozawa pers. obs.; Pocillopora damicornis, Tioho et al. 2001), 1 likely brooding species (Porites heronensis, Harriott \& Banks 1995, but see Yeemin 1991), and 1 spawning and brooding species (Oulastrea crispate, Lam 2000) were also recognized.

The most speciose family was Faviidae, with 21 species, accounting for $38.9 \%$ of the total number, followed by Mussidae ( 7 species, $13 \%$ ) and Acroporidae (6 species, $11.1 \%$ ). Faviidae were dominant in terms of both colony number and cover, constituting approximately half of the assemblage (49.8 and $55.4 \%$, respectively). Among other families, those representing $>5 \%$ of colony number were Acroporidae $(21.8 \%)$ and Poritidae $(17.8 \%)$ and those representing $>10 \%$ of cover were Pectiniidae (15.9\%), Acroporidae (11.1\%) and Merulinidae (10.5\%). At the genus level, the top 5 genera made up more than half of the assemblage in terms of both colony number $(73.4 \%)$ and cover $(62.6 \%)$. The top 5 genera in colony number were Cyphastrea $(21.9 \%)$, Acropora (21.8\%), Porites (13.9\%), Favia $(10.2 \%)$ and Goniastrea (5.6\%); the top 5 in cover were Cyphastrea (15.8\%), Echinophyllia (13.7\%), Favia (11.6\%), Acropora (11.1\%) and Hydnophora (10.5\%) (Table 2). Although 3 brooding genera ranked in the top half of dominant genera in colony number, accounting for $18.7 \%$ of the total, these were minor in terms of coral cover, constituting only $1.3 \%$ of the community (Table 2).

Size-frequency distributions of the top 15 genera in colony number are shown in Fig. 2. Descriptive statistics of the frequency distributions are summarized in Table 3. Most of the log-transformed data were more or less unimodal without clear cohorts and 5 of the 15 frequency distributions were significantly different from a normal distribution $(\mathrm{p}<0.05)$. The size frequencies of spawning genera were characterized by larger median size, wide size-range and a tendency toward negative skewness, while those of brooding genera had most colonies in small size classes with a tendency 
Table 1. Scleractinian coral species recorded in the $100 \mathrm{~m}^{2}$ study area

\begin{tabular}{|c|c|}
\hline Family & Species \\
\hline Faviidae & $\begin{array}{l}\text { Favia cf. fuvus } \\
\text { F. lizardensis } \\
\text { F. speciosa } \\
\text { F. maxima }{ }^{\mathrm{a}} \\
\text { F. veroni } \\
\text { Goniastrea australensis } \\
\text { G. deformis } \\
\text { G. fuvulus } \\
\text { G. pectinata } \\
\text { G. retiformis } \\
\text { Cyphastrea chalcidicum } \\
\text { C. microphthalma } \\
\text { C. serailia } \\
\text { Favites pentagona } \\
\text { F. russelli } \\
\text { Caulastrea tumida } \\
\text { Leptastrea purpurea } \\
\text { Montastrea valenciennesi } \\
\text { Oulastrea crispata } \\
\text { Platygyra contorta } \\
\text { Plesiastrea versipora }\end{array}$ \\
\hline Mussidae & $\begin{array}{l}\text { Acanthastrea hemprichii } \\
\text { A. bowerbanki } \\
\text { A. lordhowensis } \\
\text { A. echinata } \\
\text { A. hillae } \\
\text { Lobophyllia hemprichii } \\
\text { Micromussa amakusensis }\end{array}$ \\
\hline Acroporidae & $\begin{array}{l}\text { Acropora dendrum } \\
\text { A. cf. hyacinthus } \\
\text { A. japonica } \\
\text { A. pruinosa } \\
\text { A. solitaryensis } \\
\text { A. valida }\end{array}$ \\
\hline Pectiniidae & $\begin{array}{l}\text { Echinophyllia aspera } \\
\text { Mycedium elephantotus } \\
\text { Oxypora lacera } \\
\text { Pectinia ayleni }\end{array}$ \\
\hline Poritidae & $\begin{array}{l}\text { Alveopora cf. japonica } \\
\text { Porites heronensis } \\
\text { Goniopora lobata }\end{array}$ \\
\hline Siderastreidae & $\begin{array}{l}\text { Psammocora profundacella } \\
\text { P. superficialis } \\
\text { Coscinaraea crassa }^{\mathrm{a}}\end{array}$ \\
\hline Agariciidae & $\begin{array}{l}\text { Pavona decussata } \\
\text { P. varians }{ }^{\mathrm{a}}\end{array}$ \\
\hline Fungiidae & $\begin{array}{l}\text { Lithophyllon lobata } \\
\text { L. undulatum }\end{array}$ \\
\hline Astrocoeniidae & Stylocoeniella guentheri \\
\hline Caryophylliidae & Euphyllia ancora \\
\hline Dendrophylliidae & Turbinaria peltata \\
\hline Merulinidae & Hydnophora exesa \\
\hline Pocilloporidae & Pocillopora damicornis \\
\hline \multicolumn{2}{|c|}{ Total: 13 families, 30 genera, 54 species } \\
\hline
\end{tabular}

toward positive skewness. No tendency was seen in kurtosis for spawning and brooding genera.

\section{Community dynamics}

Of 122 (in the 2001-2002 study period) and 132 recruits (in the 2002-2003 study period) recorded (Table 4 ), the majority belonged to 4 genera-i.e. the spawning genus Acropora and the brooding genera Alveopora, Pocillopora and Porites-accounting for 82.8 and $90.9 \%$ of the total in 2001-2002 and 2002-2003, respectively. Ten other genera had 1 to 10 recruits, while remaining 16 genera had no recruits in the 2 yr study period.

Colony losses during the study period due to death (skeleton remained) and/or dislodgement (no skeleton remained) were greater than the gains due to recruitment (Table 4). Dead/lost colonies numbered 187 (21 lost) in 2001-2002 and 288 (36 lost) in 2002-2003. Lost colonies were considered as dead since there would be little chance to survive on sand or pebble seafloor at the study site. In 2001-2002, Acropora accounted for the highest proportion of dead/lost colonies $(44.4 \%$ of the total), followed by Porites (20.9\%), Alveopora (9.1\%), Favia (7.0\%) and Hydnophora (5.3\%), these 5 genera together accounting for $86.6 \%$ of the total (Table 4). In 2002-2003, this trend was largely unchanged, except the fourth and the fifth position being changed to Cyphastrea and Pocillopora, respectively. The top 5 genera in mortality in 2002-2003 were Acropora (37.5\% of the total), Porites (21.9\%), Alveopora $(8.3 \%)$, Cyphastrea (6.9\%) and Pocillopora $(6.6 \%)$, accounting for $81.3 \%$ of the total in $2002-2003$ (Table 4).

While the number of genera among dead and lost colonies was similar (14 for dead and 13 for lost), dead colonies accounted for $88 \%$ (418 colonies) of the total colony loss during the $2 \mathrm{yr}$ study period, while lost colonies accounted for only $12 \%$ (57 colonies). However, proportions were reversed with respect to cover reduction, with lost colonies accounting for $75 \%$ $\left(6730 \mathrm{~cm}^{2}\right)$ of the total lost cover and dead colonies only accounting for $25 \%\left(2208 \mathrm{~cm}^{2}\right)$. Of 57 lost colonies in this study, 3 were tabular forms (Acropora cf. hyacinthus), 7 were massive-to-branching forms (juvenile Acropora spp.), and the remaining 47 were massive-to-encrusting forms (for genera, refer to Table 4).

Size-frequency distributions of colonies with different fates (i.e. live, dead or lost at the end of study) are shown for genus (Fig. 2) and community levels (Fig. 3). At the community level, the distributions were significantly different $(H[2, \mathrm{n}=2471]=437.98, \mathrm{p}<0.001)$ between live and dead colonies (Dunn's test: $\mathrm{p}<0.001$ ) 
Table 2. The order of scleractinian genera by colony number and cover recorded in the $100 \mathrm{~m}^{2}$ study area in 2001 . Parentheses: percentage of total. Bold: brooding genera

\begin{tabular}{|c|c|c|c|c|c|}
\hline Genus & Colony no. & Rank & Genus & Cover $\left(\mathrm{cm}^{2}\right)$ & Rank \\
\hline Cyphastrea & $540(21.9)$ & 1 & Cyphastrea & 44525 (15.8) & 1 \\
\hline Acropora & 538 (21.8) & 2 & Echinophyllia & 38706 & 2 \\
\hline Porites & 344 (13.9) & 3 & Favia & 32779 (11.6) & 3 \\
\hline Favia & $253(10.2)$ & 4 & Acropora & 31317 (11.1) & 4 \\
\hline Goniastrea & $138(5.6)$ & 5 & Hydnophora & 29639 (10.5) & 5 \\
\hline Hydnophora & $92 \quad(3.7)$ & 6 & Platygyra & $19343(6.8)$ & 6 \\
\hline Alveopora & 89 (3.6) & 7 & Montastrea & 16589 (5.9) & 7 \\
\hline Leptastrea & $87 \quad(3.5)$ & 8 & Leptastrea & 16010 & 8 \\
\hline Platygyra & 82 (3.3) & 9 & Goniastrea & 12849 & 9 \\
\hline Montastrea & $75(3.0)$ & 10 & Plesiastrea & 8627 (3.1) & 10 \\
\hline Echinophyllia & 45 (1.8) & 11 & Oxypora & $5721(2.0)$ & 11 \\
\hline Psammocora & 31 (1.3) & 12 & Favites & 5434 (1.9) & 12 \\
\hline Pocillopora & 28 (1.1) & 13 & Acanthastrea & 5215 (1.8) & 13 \\
\hline Acanthastrea & $21(0.8)$ & 14 & Euphyllia & $3522(1.2)$ & 14 \\
\hline Favites & $20(0.8)$ & 15 & Porites & $2861(1.0)$ & 15 \\
\hline Oulastrea & $18(0.7)$ & 16 & Goniopora & $2672(0.9)$ & 16 \\
\hline Plesiastrea & $16(0.6)$ & 17 & Psammocora & $1765(0.6)$ & 17 \\
\hline Oxypora & $11(0.4)$ & 18 & Lobophyllia & $968(0.3)$ & 18 \\
\hline Goniopora & $7(0.3)$ & 19 & Lithophyllon & $963(0.3)$ & 19 \\
\hline Lithophyllon & $6(0.2)$ & 20 & Mycedium & $611(0.2)$ & 20 \\
\hline Micromussa & $6(0.2)$ & 20 & Turbinaria & $567 \quad(0.2)$ & 21 \\
\hline Pavona & $4 \quad(0.2)$ & 22 & Alveopora & $430(0.2)$ & 22 \\
\hline Turbinaria & $3(0.1)$ & 23 & Stylocoeniella & $352(0.1)$ & 23 \\
\hline Caulastrea & $2(0.1)$ & 24 & Coscinaraea & $313(0.1)$ & 24 \\
\hline Coscinaraea & $2(0.1)$ & 24 & Pocillopora & $260(0.1)$ & 25 \\
\hline Lobophyllia & $2(0.1)$ & 24 & Oulastrea & $240(0.1)$ & 26 \\
\hline Pectinia & $2(0.1)$ & 24 & Pavona & $106(0.0)$ & 27 \\
\hline Stylocoeniella & $2(0.1)$ & 24 & Caulastrea & $101(0.0)$ & 28 \\
\hline Euphyllia & $1(0.0)$ & 29 & Micromussa & $89(0.0)$ & 29 \\
\hline Mycedium & $1(0.0)$ & 29 & Pectinia & $18(0.0)$ & 30 \\
\hline Unidentified & 5 & & Unidentified & 5 & \\
\hline Total colonies & 2471 & & Total cover & $282595 \mathrm{~cm}^{2}$ & \\
\hline
\end{tabular}

and between dead and lost colonies (Dunn's test: $\mathrm{p}<$ 0.001) (Fig. 3). While the sizes of dead colonies ranged from 0.1 to $67.9 \mathrm{~cm}^{2}(5.3 \pm 9.0$, mean $\pm \mathrm{SD})$ with a peak in the 1 to $2 \mathrm{~cm}^{2}$ class, those of lost colonies ranged from 0.8 to $1732 \mathrm{~cm}^{2}(118.1 \pm 288.4$, mean $\pm \mathrm{SD})$ with a peak in the 16 to $32 \mathrm{~cm}^{2}$ class. At the genus level, sizefrequency distributions of live, dead and lost colonies were similar to those at community level (Fig. 2). Statistical analyses showed significant differences in size between live and dead colonies in 6 of the 8 genera tested $(p<0.01)$ and between dead and lost colonies in 3 genera tested $(\mathrm{p}<0.01)$ (Table 5$)$.

As a result of annual mortality being greater than recruitment during the study period, the total colony number was reduced by $9 \%$ from 2471 in 2001 to 2250 colonies in 2003 (Table 4). While numbers of annual recruits were almost constant, higher mortality resulted in a larger reduction in colony number in 2002-2003. Sixteen of 30 genera changed in colony number during the study period while 14 genera did not change (Table 4). Of the 16 genera that changed in colony number, only 4 genera increased (Table 4): Pocillopora increased most $(229 \%)$ in the study period from 28 to 64 colonies (+36 colonies), followed by Alveopora (+16), Acanthastrea (+1) and Psammocora (+1). For the 12 genera that decreased in colony number, Acropora decreased most (24\%) from 538 to 411 colonies ( -127 colonies), followed by Porites $(-62)$ and Cyphastrea (-22) (Table 4).

\section{DISCUSSION}

\section{Community structure}

Abundance and cover of scleractinian corals at the study site were comparable with those at other high and low latitude sites (cf. Hughes \& Tanner 2000, Harriott \& Banks 2002). The dominance of massive Faviidae may be attributed to severe waves occasionally caused by bad weather or typhoons, which tend to disturb sand and pebbles that occur with rocky substrata 




Brooding species
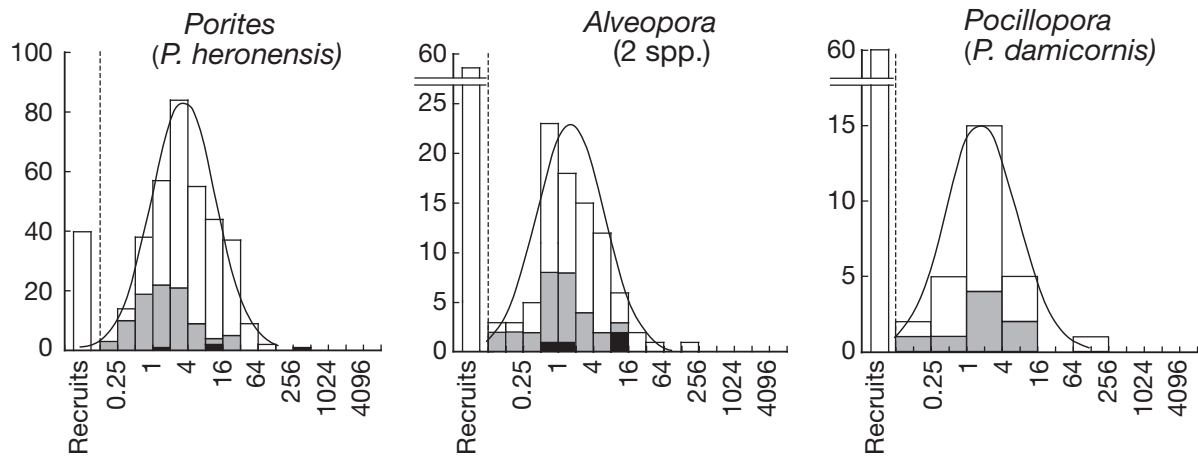

Colony size $\left(\mathrm{cm}^{2}, \log _{2}\right.$ scale)

Fig. 2. Colony-size frequency distributions of the 15 most abundant scleractinian genera. A normal distribution is superimposed on each histogram. Parentheses: number of species included, or species name if only 1 species occurs (cf. Table 1). Colony fate (by end of 2 yr study period) - white bars: live; grey: dead; black: lost. Recruits shown at left. Note that size-class intervals are wider for genera with $<50$ colonies 
Table 3. Descriptive statistics of logarithmically transformed size-distribution data for the top 15 genera by colony number (see Table 2). $\mathrm{P}_{\text {norm: }}$ : probability of departure of the distribution from normality, only where the value is $<0.05$ (D'Agostino-Pearson test with Bonferroni correction). For 5 genera with $\mathrm{P}_{\text {norm }}<0.05$, normality of kurtosis and skewness were further tested (Anscombe-

Glynn test of kurtosis and D'Agostino test of skewness, both with Bonferroni correction). ${ }^{*} \mathrm{p}<0.05,{ }^{* *} \mathrm{p}<0.01$

\begin{tabular}{|c|c|c|c|c|c|c|}
\hline Genus & Median $\left(\mathrm{cm}^{2}\right)$ & Range $\left(\mathrm{cm}^{2}\right)$ & Kurtosis & Skewness & $\mathrm{P}_{\text {norm }}$ & $\mathrm{n}$ \\
\hline \multicolumn{7}{|l|}{ Spawners } \\
\hline Сyphastrea & 40.1 & 1695.9 & 0.311 & $-0.448^{*}$ & $<0.01$ & 540 \\
\hline Acropora & 11.1 & 2420.9 & 0.453 & 0.145 & & 538 \\
\hline Favia & 40.0 & 2651.8 & $-0.830^{* *}$ & -0.347 & $<0.001$ & 253 \\
\hline Goniastrea & 35.7 & 1349.5 & 0.350 & -0.255 & & 138 \\
\hline Hydnophora & 133.7 & 5976.9 & 0.710 & -0.901 & $<0.05$ & 92 \\
\hline Leptastrea & 94.3 & 1165.2 & 1.791 & -0.968 & $<0.01$ & 87 \\
\hline Platygyra & 85.0 & 1442.5 & -0.796 & -0.402 & & 82 \\
\hline Montastrea & 15.6 & 1993.7 & $-1.278^{* *}$ & 0.131 & $<0.001$ & 75 \\
\hline Echinophyllia & 191.0 & 6812.8 & -0.642 & -0.391 & & 45 \\
\hline Psammocora & 9.8 & 1007.4 & 1.208 & 0.953 & & 31 \\
\hline Acanthastrea & 118.0 & 1080.4 & -0.906 & -0.535 & & 21 \\
\hline Favites & 85.6 & 2414.1 & -0.408 & -0.059 & & 20 \\
\hline \multicolumn{7}{|l|}{ Brooders } \\
\hline Porites & 3.3 & 331.0 & -0.211 & 0.179 & & 344 \\
\hline Alveopora & 1.5 & 132.5 & 0.483 & 0.382 & & 89 \\
\hline Pocillopora & 2.0 & 197.0 & 3.885 & 0.750 & & 28 \\
\hline
\end{tabular}

Table 4. Change in number of colonies, dead colonies and recruits in the $100 \mathrm{~m}^{2}$ area from 2001 to $2003 . \Delta, \boldsymbol{\nabla}$ : increase or decrease, respectively, in colony number compared to the previous year, or throughout the study period. Parentheses: number of lost colonies. Bold: brooding genera

\begin{tabular}{|c|c|c|c|c|c|c|c|c|}
\hline \multirow{2}{*}{ Genus } & \multirow{2}{*}{$\begin{array}{c}2001 \\
\text { Colony no. }\end{array}$} & \multicolumn{2}{|c|}{ 2001-2002 } & \multirow{2}{*}{$\begin{array}{c}2002 \\
\text { Colony no. }\end{array}$} & \multicolumn{2}{|c|}{ 2002-2003 } & \multirow{2}{*}{$\begin{array}{c}2003 \\
\text { Colony no. }\end{array}$} & \multirow{2}{*}{$\begin{array}{c}\text { 2001-2003 } \\
\text { Change }\end{array}$} \\
\hline & & Dead & Recruit & & Dead & Recruit & & \\
\hline Cyphastrea & 540 & $6(2)$ & 3 & $\boldsymbol{\nabla} 537$ & $20(4)$ & 1 & $\nabla 518$ & $\boldsymbol{\nabla}-22$ \\
\hline Acropora & 538 & 83 (3) & 26 & $\nabla 481$ & 108 & 38 & $\nabla 411$ & $\boldsymbol{\nabla}-127$ \\
\hline Porites & 344 & 39 (2) & 17 & $\nabla 322$ & $63(2)$ & 23 & $\nabla 282$ & $\nabla-62$ \\
\hline Favia & 253 & $13(1)$ & 5 & $\boldsymbol{\nabla} 245$ & $14(7)$ & 2 & $\boldsymbol{\nabla} 233$ & $\boldsymbol{\nabla}-20$ \\
\hline Goniastrea & 138 & $4(4)$ & & $\nabla 134$ & $6(4)$ & 1 & $\nabla 129$ & $\boldsymbol{\nabla}-9$ \\
\hline Hydnophora & 92 & $10(5)$ & 8 & $\nabla 90$ & 5 & 2 & $\nabla 87$ & $\boldsymbol{\nabla}-5$ \\
\hline Alveopora & 89 & 17 (1) & 29 & $\Delta 101$ & $24(3)$ & 28 & $\Delta 105$ & $\Delta+16$ \\
\hline Leptastrea & 87 & 1 & & $\nabla 86$ & & & 86 & $\boldsymbol{\nabla}-1$ \\
\hline Platygyra & 82 & 1 & 1 & 82 & $5(1)$ & 1 & $\boldsymbol{\nabla} 78$ & $\boldsymbol{\nabla}-4$ \\
\hline Montastrea & 75 & 4 (1) & 1 & $\nabla 72$ & $14(3)$ & & $\boldsymbol{\nabla} 58$ & $\boldsymbol{\nabla}-17$ \\
\hline Echinophyllia & 45 & 2 (1) & 1 & $\nabla 44$ & 5 (3) & 1 & $\nabla 40$ & $\boldsymbol{\nabla}-5$ \\
\hline Psammocora & 31 & & 1 & $\Delta 32$ & 1 & 1 & 32 & $\Delta+1$ \\
\hline Pocillopora & 28 & 5 & 29 & $\Delta 52$ & 19 & 31 & $\Delta 64$ & $\Delta+36$ \\
\hline Acanthastrea & 21 & & 1 & $\Delta 22$ & & & 22 & $\Delta+1$ \\
\hline Favites & 20 & & & 20 & & & 20 & \\
\hline Oulastrea & 18 & & & 18 & & & 18 & \\
\hline Plesiastrea & 16 & & & 16 & & & 16 & \\
\hline Oxypora & 11 & 1 & & $\nabla 10$ & $1(1)$ & & $\nabla 9$ & $\boldsymbol{\nabla}-2$ \\
\hline Goniopora & 7 & 1 (1) & & $\nabla 6$ & & 1 & $\Delta 7$ & \\
\hline Lithophyllon & 6 & & & 6 & $1(1)$ & & $\bar{\nabla} 5$ & $\boldsymbol{\nabla}-1$ \\
\hline Micromussa & 6 & & & 6 & & & 6 & \\
\hline Pavona & 4 & & & 4 & & & 4 & \\
\hline Turbinaria & 3 & & & 3 & & & 3 & \\
\hline Caulastrea & 2 & & & 2 & & & 2 & \\
\hline Coscinaraea & 2 & & & 2 & & & 2 & \\
\hline Lobophyllia & 2 & & & 2 & & & 2 & \\
\hline Pectinia & 2 & & & 2 & & & 2 & \\
\hline Stylocoeniella & 2 & & & 2 & & & 2 & \\
\hline Euphyllia & 1 & & & 1 & & & 1 & \\
\hline Mycedium & 1 & & & 1 & & & 1 & \\
\hline Unidentified & 5 & & & 5 & 2 & 2 & 5 & \\
\hline Total & 2471 & 187 (21) & 122 & $\boldsymbol{\nabla} 2406$ & $288(36)$ & 132 & $\boldsymbol{\nabla} 2250$ & $\boldsymbol{\nabla}-221$ \\
\hline
\end{tabular}




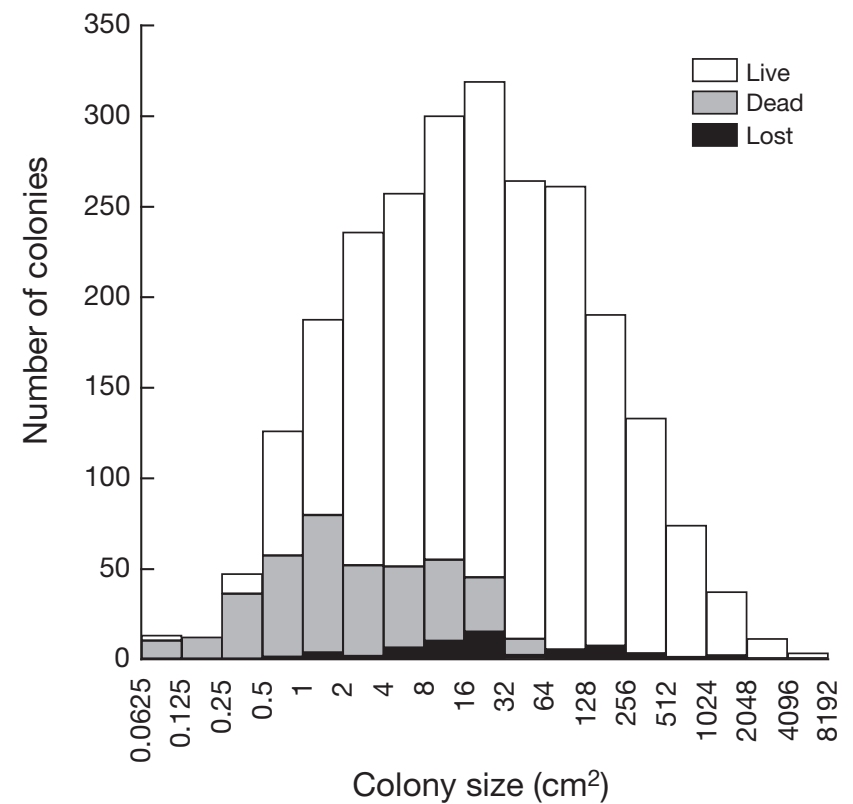

Fig. 3. Comparison of size frequency distributions of colonies with different fate (alive, dead or lost). Colony sizes refer to 2001

Table 5. Comparisons of logarithmically transformed size-frequency distributions between live (L), dead (D) and lost (Lst) colonies in each genus (cf. Fig. 2). A Kolmogorov-Smirnov 2 -sample test (KS test) was conducted for genera with $>5$ dead or lost colonies. A Dunn's multiple comparison test (Dunn test) was conducted for genera with $>5$ dead and $>5$ lost colonies. p-values were corrected by Bonferroni method. ns: not significant

\begin{tabular}{|c|c|c|c|c|c|}
\hline \multirow{3}{*}{ Genus } & & & \multicolumn{3}{|l|}{ p-values } \\
\hline & \multicolumn{2}{|c|}{ KS test } & \multicolumn{3}{|c|}{ Dunn test } \\
\hline & L - D & L - Lst & $L-D$ & L - Lst & D - Lst \\
\hline Cyphastrea & $>0.01$ & & ns & ns & $>0.01$ \\
\hline Acropora & $>0.01$ & & ns & $\mathrm{ns}$ & $>0.01$ \\
\hline Porites & $>0.01$ & & & & \\
\hline Favia & $>0.01$ & & ns & ns & $>0.01$ \\
\hline Goniastrea & & $\mathrm{ns}$ & & & \\
\hline Hydnophora & $>0.01$ & & & & \\
\hline Alveopora & ns & & & & \\
\hline Montastrea & $>0.01$ & & & & \\
\hline Pocillopora & $\mathrm{ns}$ & & & & \\
\hline
\end{tabular}

at the study site. The strongest typhoon experienced in 2002-2003 moved even boulders of a few meters in diameter and slightly changed the underwater topography. These physical disturbances may cause significant damage to morphologically more vulnerable taxa (e.g. laminar Acropora species), thereby inhibiting the development of populations. In addition, competition with macro algae and seaweed may also slow or limit population development of fast growing but physically vulnerable species, e.g. Acropora and Pocillopora species (e.g. van Woesik et al. 1995). In the course of the present study, an outbreak of the seaweed Colpomenia sinuosa was observed in March to April 2003, which resulted in an extensive overshadowing/smothering of coral colonies for 2 to $3 \mathrm{wk}$ and their partial death/ bleaching, especially among Acropora species and $P$. damicornis.

In size-frequency distribution analyses, the absence of distinguishable cohorts in scleractinian genera may be due to large growth variation and reduction of colony size by partial tissue death and fission (Hughes \& Jackson 1985, Babcock 1991, Bak \& Meesters 1998, Meesters et al. 2001). Overall characteristics of sizefrequency distributions in brooding and spawning genera were similar to those described by Vermeij \& Bak (2002), who observed small colony sizes and positive skewness in brooding species and large colony sizes and negative skewness in spawning ones. The difference in skewness may be attributable to different recruitment rates of brooding and spawning species (Vermeij \& Bak 2002). Generally, high recruitment rates may increase colonies in small size classes, skewing the distribution to the right, and vice versa. In the present study, one spawning genus, Acropora, dominated annual recruitment along with 3 brooding genera that also showed a slightly positive skewness, unlike most spawning genera.

\section{Community dynamics}

Annual recruitment (1.2 to 1.3 recruits $\mathrm{m}^{-2}$ ) and mortality (1.9 to 2.9 dead colonies $\mathrm{m}^{-2}$ ) recorded in this study were within the ranges reported by Harriott \& Smith (2002) at another high latitude site, the Solitary Islands, Australia $\left(30^{\circ} \mathrm{S}_{;} 0.1\right.$ to 3.9 recruits $\mathrm{m}^{-2}$ and 0.22 to 3.99 dead colonies $\mathrm{m}^{-2}$ ). Although the annual recruitment rates were lower than most of those reported at tropical reef sites (2 to 16 recruits $\mathrm{m}^{-2}$ ) (Harriott \& Smith 2002), given widely documented low recruitment rates in high latitude scleractinian communities (Hughes et al. 2002), these must be sufficient to maintain scleractinian populations in high-latitude localities (Harriott 1999). There is some difficulty in comparing mortality among different reef sites due to considerable variation in estimated annual mortality rates (0 to $65 \%$ ) and differences in methodology (Harriott \& Smith 2002).

Most scleractinian genera showed no or little change in colony number throughout the study period. This stability seems to be a feature of high-latitude scleractinian communities, as it has been observed at other high latitude sites, such as the Solitary Islands (Harriott $\&$ Smith 2002) and Lord Howe Island, Australia $\left(31^{\circ} \mathrm{S}\right)$ 
(Harriott et al. 1995). However, since most of the genera here consisted of small a number of colonies with few annual recruits, species composition of the community may vary considerably over a long time scale, due to local extinction of rare species and chance recruitment of new species. Harriott et al. (1994) reported that 21 of 55 scleractinian coral species previously recorded at the Solitary Islands were not found in their study, indicating dynamic temporal patterns of species recruitment and replacement occurring in high-latitude scleractinian communities.

During the study period, many colonies were completely lost from the monitored area by severe wave action. The unique feature of this phenomenon was that colonies of large size classes were occasionally lost while colonies that died from other causes were mostly of small size classes. As a consequence, lost colonies, though small in numbers, mostly accounted for reduction in coral cover. Dislodgement of colonies from substrata may be facilitated by the relatively smooth surface characteristics of rocks that are a major component of substrata at high latitudes (Harriott et al. 1994, 1995, 1999, Banks \& Harriott 1995). General lack of dead coral skeletons in the area may also be attributable to this phenomenon. Thus, the occasional loss of large colonies and dead coral skeletons by severe wave action is likely to be a significant factor inhibiting the development of scleractinian assemblages and reef accretion (Dollar \& Tribble 1993, Grigg 1998, Harriott \& Smith 2002), especially at high latitudes where these processes are considered to be slow (Harriott \& Banks 2002). In this respect, it is interesting to note that, despite the reported occurrence of many scleractinian communities in subtropical to temperate localities (e.g. Harriott et al. 1994, 1995, 1999, Banks \& Harriott 1995, Yamano et al. 2001, The Japanese Coral Reef Society \& Ministry of the Environment 2004), only the highest latitude localities support apparent coral reef formation in both the northern and southern hemispheres, i.e. Lord Howe Island $\left(31^{\circ} \mathrm{S}\right)$ (Harriott et al. 1995) and Iki Island, Japan $\left(33^{\circ} \mathrm{N}\right)$ (Yamano et al. 2001). This may be related to the fact that the frequency and magnitude of disturbance by cyclones/typhoons are reduced at higher latitudes.

Acknowledgements. We thank Dr. J. D. Reimer and an anonymous reviewer for correcting the English of this manuscript and providing detailed comments. This study was supported by a Research Fellowship for Young Scientists (Y.N.), a research grant from the Kurita Water and Environmental Foundation (Y.N.), the Kyushu University P \& P program, the 21st century COE program of the Japan Ministry of Education, Culture, Sports, Science and Technology, and the scientific research grant ('Grant-In-Aid' Nos. 14340246 and 14255013 to M.T.) from the Japan Society for the Promotion of Science.

\section{LITERATURE CITED}

Babcock RC (1991) Comparative demography of three species of scleractinian corals using age- and size-dependent classifications. Ecol Monogr 61:225-244

Bak RPM, Meesters EH (1998) Coral population structure: the hidden information of colony size-frequency distributions. Mar Ecol Prog Ser 162:301-306

Banks SA, Harriott VJ (1995) Coral communities of the Gneering Shoals and Mudjimba Island, south-eastern Queensland. Mar Freshw Res 46:1137-1144

Dollar S, Tribble GW (1993) Recurrent storm disturbance and recovery: a long-term study of coral communities in Hawaii. Coral Reefs 12:223-233

Grigg RW (1998) Holocene coral reef accretion in Hawaii: a function of wave exposure and sea level history. Coral Reefs 17:263-272

Hall VR, Hughes TP (1996) Reproductive strategies of modular organisms: comparative studies of reef-building corals. Ecology 77:950-963

Harriott VJ (1999) Coral recruitment at a high latitude Pacific site: a comparison with Atlantic reefs. Bull Mar Sci 65: 881-891

Harriott VJ, Banks SA (1995) Recruitment of scleractinian corals in the Solitary Islands Marine Reserve, a high latitude coral-dominated community in Eastern Australia. Mar Ecol Prog Ser 123:155-161

Harriott VJ, Banks SA (2002) Latitudinal variation in coral communities in eastern Australia: a qualitative biophysical model of factors regulating coral reefs. Coral Reefs 21: 83-94

Harriott VJ, Smith SDA (2002) Coral population dynamics in a subtropical coral community, Solitary Islands Marine Park, Australia. Proc 9th Int Coral Reef Symp 1: 573-581

Harriott VJ, Smith SDA, Harrison PL (1994) Patterns of coral community structure of subtropical reefs in the Solitary Islands Marine Reserve, Eastern Australia. Mar Ecol Prog Ser 109:67-76

Harriott VJ, Harrison PL, Banks SA (1995) The coral communities of Lord Howe Island. Mar Freshw Res 46:457-465

$>$ Harriott VJ, Banks SA, Mau RL, Richardson D, Roberts LG (1999) Ecological and conservation significance of the subtropical rocky reef communities of northern NEW South Wales, Australia. Mar Freshw Res 50:299-306

Hughes TP, Jackson JB (1985) Population dynamics and life histories of foliaceous corals. Ecol Monogr 55:141-166

Hughes TP, Tanner JE (2000) Recruitment failure, life histories, and long-term decline of Caribbean corals. Ecology 81:2250-2263

Hughes TP, Baird AH, Dinsdale EA, Harriott VJ and others (2002) Detecting regional variation using meta-analysis and large-scale sampling: latitudinal patterns in recruitment. Ecology 83:436-451

Japanese Coral Reef Society, Ministry of the Environment (ed) (2004) Coral Reefs of Japan. Ministry of the Environment, Tokyo

Lam KKY (2000) Sexual reproduction of a low temperature tolerant coral, Oulastrea crispata, in Hong Kong, China. Mar Ecol Prog Ser 205:101-111

Meesters EH, Hilterman M, Kardinaal E, Keetman M, deVries M, Bak RPM (2001) Colony size-frequency distributions of scleractinian coral populations: spatial and interspecific variation. Mar Ecol Prog Ser 209:43-54

Nishihira M, Veron JEN (1995) Hermatypic corals of Japan. Kaiyusha, Tokyo (in Japanese)

Nozawa Y, Tokeshi M, Nojima S (2006) Reproduction and recruitment of scleractinian corals in a high-latitude coral 
community, Amakusa, southwestern Japan. Mar Biol 149: $1047-1058$

R Development Core Team (2005) R: a language and environment for statistical computing. R Foundation for Statistical Computing, Vienna

Thamrin, Nojima S, Tokeshi M (2001) Experimental analysis of planula release in a scleractinian coral Alveopora japonica. Galaxea, JCRS 3:25-30

Tioho H, Tokeshi M, Nojima S (2001) Experimental analysis of recruitment in a scleractinian coral at high latitude. Mar Ecol Prog Ser 213:79-86

Tokeshi M (1999) Species coexistence: ecological and evolutionary perspectives. Blackwell Science, Oxford

van Woesik R, De Vantier LM, Glazebrook JS (1995) Effects of cyclone 'Joy' on nearshore coral communities of the Great Barrier Reef. Mar Ecol Prog Ser 128:261-270

Initial editorial responsibility: Howard Browman, Storebø, Norway (until November 5, 2007); Final editorial responsibility: Matthias Seaman, Oldendorf/Luhe, Germany
Vermeij MJA, Bak RPM (2002) Inferring demographic processes from population size structure in corals. Proc 9th Int Coral Reef Symp 1:589-593

Veron JEN (1992) Hermatypic corals of Japan. Australian Institute of Marine Science Monograph Series 9, Townsville

Veron JEN (2000) Corals of the World. Australian Institute of Marine Science \& CRR Qld, Townsville

Yamano H, Hori K, Yamauchi M, Yamagawa O, Ohmura A (2001) Highest-latitude coral reef at Iki Island, Japan. Coral Reefs 20:9-12

Yeemin T (1991) Ecological studies of scleractinian coral communities above the northern limit of coral reef development in the western Pacific. PhD thesis, Kyushu University, Fukuoka

Zar JH (1999) Biostatistical analysis, 4th edn. Prentice Hall, Upper Saddle River, NJ

Submitted: July 2, 2007; Accepted: November 19, 2007

Proofs received from author(s): April 9, 2008 